\title{
Tardigrades of the Australian Antarctic: Hypsibius heardensis (Eutardigrada: Hypsibiidae: dujardini group) a new species from sub-Antarctic Heard Island
}

\author{
WILLIAM R. MILLER ${ }^{1}$, SANDRA J. MCINNES ${ }^{2}, \&$ DANA M. BERGSTROM ${ }^{3}$ \\ ${ }^{1}$ Dept. of Biology, Baker University, Baldwin City, Kansas 66006 U.S.A., email: William.Miller@BakerU.edu \\ ${ }^{2}$ British Antarctic Survey, Natural Environment Research Council, Madingley Road, Cambridge CB3 OET, \\ United Kingdom,email:sjmc@bas.ac.uk \\ ${ }^{3}$ Australian Antarctic Division, 203 Channel Highway, Kingston Tasmania 7050, Australia, email: \\ Dana.Bergstrom@aad.gov.au
}

\begin{abstract}
A new species, Hypsibius heardensis sp. nov. (Tardigrada: Eutardigrada: Hypsibiidae) is described from samples collected during the Australian National Antarctic Research Expeditions (ANARE) 1986-87 expedition to Heard Island, in the southern Indian Ocean. The new species belongs to the dujardini group and differs from similar species of Hypsibius by the absence of eyes, large apophyses, near equal macroplacoids, lack of a microplacoid, the presence of a small septulum, and cuticular bars near the base of all claws.
\end{abstract}

Key words: Tardigrada, Hypsibius heardensis sp. nov., Heard Island, Antarctica

\section{Introduction}

Heard Island $\left(53^{\circ} 06^{\prime} \mathrm{S}, 73^{\circ} 30^{\prime} \mathrm{E}\right)$ (Figs $1 \mathrm{~A}, \mathrm{~B}$ ), is located in the southern Indian Ocean to the south of the Polar Frontal Zone, only $1650 \mathrm{~km}$ north of Antarctica, and about midway between Australia (4350 km to the east), and South Africa (4850 km to the west) (Clark et al. 1983). The island is mainly volcanic, built on pelagic limestone of Miocene age (Barling 1990; Clarke et al. 1983), and approximately $40 \mathrm{~km}$ long by $20 \mathrm{~km}$ wide (an area of $367 \mathrm{~km}^{2}$ ), with one main peak, Big Ben, rising to $2745 \mathrm{~m}$ (Allison \& Keage 1986). Though extensively ice covered, between 1985 and 2000/01 there has been a substantial reduction in ice extent, which has reduced from over $80 \%$ to approximately $69 \%$ of total surface area (Ruddell, per. comm.). 